\title{
Phytochemical studies on the seeds, pseudofruits, and roots of Rosa pimpinellifolia
}

\author{
Leyla GÜVEN ${ }^{1}$ * (D), Ufuk ÖZGEN 2 (D), Hasan SEÇEN ${ }^{3}(\mathbb{D})$, Sıla Özlem ŞENER 2 (D), Merve BADEM ${ }^{4}$ (D), \\ Gonca ÇELIK ${ }^{5}$ (D), Nurettin YAYLI ${ }^{2}$
}

1 Department of Pharmaceutical Botany, Faculty of Pharmacy, Atatürk University, Erzurum, 25240, Turkey.

2 Department of Pharmacognosy, Faculty of Pharmacy, Karadeniz Technical University, Trabzon, 61080, Turkey.

3 Department of Chemistry, Faculty of Sciences, Atatürk University, Erzurum, 25240, Turkey.

4 Department of Biochemistry, Faculty of Pharmacy, Karadeniz Technical University, Trabzon, 61080, Turkey.

5 Department of Chemistry, Faculty of Sciences, Karadeniz Technical University, Trabzon, 61080, Turkey.

* Corresponding Author. E-mail: leyla.guven@atauni.edu.tr (L.G.); Tel. +90-442-231 5238.

Received: 17 September 2020 / Revised: 12 January 2021/ Accepted: 15 February 2021

\begin{abstract}
The roots and pseudofruits of Rosa pimpinellifolia (Rosaceae) are used in traditional medicine as hemorrhoids, various infections, abdominal pain complaints, heart disease, flu, cold, and anemia treatment in Turkey. In this study, the phytochemical composition of the $R$. pimpinellifolia was revealed by using chromatographic and spectroscopic techniques. Two condensed tannin precursor, (-)-catechin (1), the mixture of catechin and epicatechin (2) and three triterpenoid glycosides, kaji-ichigoside F1 (3), $2 a, 3 \beta, 19 a$ trihydroxyurs-12-en-28-O- $\beta$-D-glucopyranoside (4), $2 a, 3 \beta, 19 a, 23 \beta$-tetrahydroxyurs-12-en-28-O- $\beta$-D-glucopyranoside (5) were isolated from the roots of $R$. pimpinellifolia. The isolation studies were performed by column chromatography. The chemical structures of the isolated compounds were elucidated with $1 \mathrm{H}$ and 13C NMR spectroscopy. Total phenolic compound contents were determined as $31.1937 \mathrm{mg} / \mathrm{g}$ dry extract in the pseudofruit; $9.8909 \mathrm{mg} / \mathrm{g}$ dry extract in the root via HPLC. The seeds of R. pimpinellifolia were extracted with diethyl ether in Soxhlet apparatus. The methyl esters of fatty acid were obtained from fixed oil and analyzed by GC/MS. The total ratio of unsaturated fatty acids in the seeds was $93.4 \%$; containing $51.40 \%$ ratio of linoleic acid and $41.20 \%$ ratio of homo- $\gamma$-linolenic acid.
\end{abstract}

KEYWORDS: Rosa pimpinellifolia; Triterpenoid glycosides; phenolic compounds; fatty acid.

\section{INTRODUCTION}

Rosa (Rosaceae) genus, known as "Gül, Kuşburnu" in Turkey, has 24 species [1, 2]. In Turkey, $R$. pimpinellifolia L. is known as "karakuşburnu, koyungözü" and its synonym is also used as R. spinossima L. in the literature. R. pimpinellifolia is used in traditional medicine as tea alone or in a mixture with other herbs for hemorrhoids, various infections, abdominal pain complaints, heart disease, flu, cold, and anemia treatment [3-6].

Rosehip known as vitamin C source is used for preparing baby food, fruit juice, marmalade, tea, wine, and also as an additive ingredient in the pastry and confectionery industry [7]. It is usually added in medicinal preparations as a vitamin $C$ source [8]. Ascorbic acid has a cytotoxic effect on cancer cells and cannot cause damage because they are resistant to healthy cells [9]. There is a good correlation between antioxidant activity and vitamin $C$ as well as phenolic compounds [9-11].

Rosehip oil is rich in essential fatty acids, carotenoids, and vitamin A (retinol). Due to its rich chemical content, the cosmetic industry uses the oil in moisturizing and anti-aging as well as skin problems such as dermatitis, eczema, acne, burns [12]. "Essential Fatty Acids" are fatty acids having more than two bonds, cannot be produced in the human body, and should be taken by diet, [13, 14]. Essential fatty acids have four basic tasks in the body: (i) modulation of membrane structure, (ii) the formation of eicosanoids (prostaglandins, leukotrienes, and thromboxanes), (iii) control of possible permeability of other membranes such as the digestive tract and blood-brain barrier, (iv) regulation of cholesterol transport and cholesterol synthesis [15-17].

How to cite this article: Güven L, Özgen U, Seçen H, Şener SÖ, Badem M, Çelik G, Yaylı N. Phytochemical studies on the seeds, pseudofruits and roots of Rosa pimpinellifolia. J Res Pharm. 2021; 25(2): 153-163. 
Flavonoid derivatives [18], anthocyanidins [19], aurons [20], phenolic acids [21], phenylethanoids and glycosides [22], triterpenic compounds [23], steroidal compounds [24], sesquiterpenes [25], carotenoids [26], tannins [18], fatty acids [27], and essential oil [28] are found in the contents of pseudofruits, seeds, leaves, and flowers of Rosa species. These findings are in line with the outcomes of the previous studies conducted by the roots of R. heckeliana [21], R. davurica [29, 30], R. taiwanensis[31], R. multiflora [32-34], R. laevigata [35, 36], R. odorata var. gigantean [37], and R. rugosa [38].

Some biological activity studies conducted on the roots of Rosa species reported that root extracts including condensed tannins and triterpenes have anti-inflammatory and hepatoprotective activites [30, 3941]. Çoruh et al. reported that catechin and epicatechin, isolated from the roots of $R$. heckeliana, have anticancer activity [39]. An et al. reported that kaji-ichygoside F1, rosamultin, euchaphic acid, and tormentic acid isolated from the roots of $R$. rugosa, also have antinociceptive and anti-inflammatory activity [38]. These results made us suggest that $R$. pimpinellifolia roots may be a rich source for important biological activities.

Although there hasn't been much research on R. pimpinellifolia, Porter et al. reported that the systematic characters of Rosa genus are with flavonol glycosides acylated with 3-hydroxy-3-methylglutaric acid. In their study performed on $R$. pimpinellifolia's leaves, 3-O-a-L-rhamnopyranosyl-(1 $\rightarrow 2)$-[6-O-(3-hydroxy-3methylglutaryl)- $\beta$-D-galactopyranosides] of kaempferol (3,5,7,4' -tetrahydroxyflavone) and quercetin (3,5,7, 3',4' -pentahydroxyflavone) were reported [42].

Biological activity studies conducted on R. pimpinellifolia pseudofruits report remarkable results. One of these conducted by Mavi et al. showed that there are high antioxidant activities of $R$. pimpinellifolia pseudofruits via peroxidation inhibitory and DPPH activity mechanisms [43].

Although there are some studies in the literature reporting various biological activities and chemical composition of $R$. pimpinellifolia pseudofruit; there is no available study conducted on the chemical composition of $R$. pimpinellifolia roots. Our study has an original value of investigating the chemical composition of $R$. pimpinellifolia roots.

This study aims to determine the chemical composition of R. pimpinellifolia plant used in traditional medicine. Thus, it can be a pioneer for investigating the different pharmacological activities of Rosa species from roots to fruit.

\section{RESULTS}

\subsection{Isolation and structure identification}

At the beginning of the study, the roots of $R$. pimpinellifolia were extracted with $\mathrm{MeOH}$ and its chemical contents were obtained by column chromatography. ${ }^{1} \mathrm{H}$ NMR and ${ }^{13} \mathrm{C}$ NMR data of the known compounds were in line with data given in the literature for (-) catechin [44], epicatechin [45], Kaji-ichigoside F1 [46], $2 a$, $3 \beta, 19 a$ trihydroxyurs-12-en-28-O- $\beta$-D-glucopyranoside [47-49], $2 a, 3 \beta, 19 a, 23 \beta$-tetrahydroxyurs-12-en-28-O- $\beta$ D-glucopyranoside [50, 51] (Figure 1).

\subsubsection{Compound 1 ((-) catechin)}

${ }^{1} \mathrm{H}$ NMR $\left(400 \mathrm{MHz}, \mathrm{CD}_{3} \mathrm{OD}\right) \delta 6.82\left(d, 1 \mathrm{H}, \mathrm{H}-2^{\prime}, J=1.8 \mathrm{~Hz}\right), 6.75\left(d, 1 \mathrm{H}, \mathrm{H}-5^{\prime} J=8.0 \mathrm{~Hz}\right), 6.70 \mathrm{dd}, 1 \mathrm{H}, \mathrm{H}-$ $\left.6^{\prime}, J=1.8,8.0 \mathrm{~Hz}\right), 5.92(d, 1 \mathrm{H}, \mathrm{H}-8 \mathrm{~J}=2.2), 5.84(d, 1 \mathrm{H}, \mathrm{H}-6, J=2.2), 4.55(d, 1 \mathrm{H}, \mathrm{H}-2, J=7.7), 3.96(d d d, 1 \mathrm{H}, \mathrm{H}-$ $3, J=(7.7,5.5,8.3), 2.49$ (dd, 1H, H-4a, $J=16.1,8.3), 2.83(d d, 1 \mathrm{H}, \mathrm{H}-4 \mathrm{~b} J=16.1,5.5) .{ }^{13} \mathrm{C}-\mathrm{NMR}\left(100 \mathrm{MHz}, \mathrm{CD}_{3} \mathrm{OD}\right)$ $\delta 156.4$ (C-7), 156.7 (C-5), 155.7 (C-9), 145.1 (C-3',C-4'), 131.0 (C-1'), 118.8 (C-6'), 114.9 (C-2'), 114.1 (C-5'), 99.6 (C-10), 95.1 (C-6), 94.3 (C-8), 81.7 (C-2), 67.6 (C-3), 27.3 (C-4). ${ }^{1} \mathrm{H}$ NMR and ${ }^{13} \mathrm{C}$ NMR data were in agreement with data given in the literature for (-) catechin [44] (Figure S1, S2).

\subsubsection{Compounds 2 (The mixture of catechin and epicatechin)}

Catechin. ${ }^{1} \mathrm{H}$ NMR and ${ }^{13} \mathrm{C}$ NMR data of catechin in the mixture were in agreement with the data given above. Epicatechin. ${ }^{1} \mathrm{H}$ NMR $\left(400 \mathrm{MHz}, \mathrm{CD}_{3} \mathrm{OD}\right) \delta 6.95\left(d, 1 \mathrm{H}, \mathrm{H}-2^{\prime}, J=2.0 \mathrm{~Hz}\right), 6.79\left(d d, 1 \mathrm{H}, \mathrm{H}-6{ }^{\prime}, J=2.0,8.2\right.$ $\mathrm{Hz}), 6.75\left(d, 1 \mathrm{H}, \mathrm{H}-5^{\prime} J=8.2 \mathrm{~Hz}\right), 5.93(d, 1 \mathrm{H}, \mathrm{H}-6, J=2.2), 5.90(d, 1 \mathrm{H}, \mathrm{H}-8 \mathrm{~J}=2.2$ ), $4.2(\mathrm{bs}, \mathrm{H}-2,1 \mathrm{H}), 3.82(\mathrm{~m}$, 1H, H-3), 2.85 (dd, 1H, H-4b, J =16.1, 5.8), $2.73(d d, 1 \mathrm{H}, \mathrm{H}-4 \mathrm{a}, J=16.1,3.0) .{ }^{13} \mathrm{C}-\mathrm{NMR}\left(100 \mathrm{MHz}, \mathrm{CD}_{3} \mathrm{OD}\right) \delta 156.4$ (C-7), 156.5 (C-5), 155.7 (C-9), 145.1 (C-3', C-4'), 131.0 (C-1'), 118.8 (C-6'), 114.9 (C-2'), 114.1 (C-5'), 99.6 (C-10), 95.1 (C-6), 94.3 (C-8), 81.7 (C-2), 67.6 (C-3), 27.3 (C-4). ${ }^{1} \mathrm{H}$ NMR and ${ }^{13} \mathrm{C}$ NMR data were in agreement with data given in the literature for epicatechin [45] (Figure S3, S4). 


\subsubsection{Compound 3 (Kaji-ichigoside $\mathrm{F}_{1}$ )}

${ }^{1} \mathrm{H}$ NMR (400 MHz, CD $\left.{ }_{3} \mathrm{OD}\right) \delta 5.30(d, 1 \mathrm{H}, \mathrm{H}-1$ ', $J=8.0), 5.30(s, 1 \mathrm{H}, \mathrm{H}-12), 3.9(m, 1 \mathrm{H}, \mathrm{H}-2), 3.3(m, 1 \mathrm{H}$, H-3), 3.79 (dd, 2H, H-6' $J=12.09,1.83), 3.67$ (dd, 2H, H-6', 2H J = 11.73, 4.4), 3.3-3.64 ( $m$, 1H, sugar protons, H2', H-3', H-4' , H-5'), 2.59 (ddd, 2H, H-16, J = 4.0, 9.2), 2.5 (s, 1H, H-18), 1.99 (m, 2H, H-11), 1.81 (m, 2H, H-15), 1.8 ( $m, 1 \mathrm{H}, \mathrm{H}-9), 1.78$ ( $m, 2 \mathrm{H}, \mathrm{H}-22), 1.57$ ( $m, 2 \mathrm{H}, \mathrm{H}-7), 1.55$ ( $m, 2 \mathrm{H}, \mathrm{H}-1), 1.4(m, 2 \mathrm{H}, \mathrm{H}-6), 1.32$ (s, H-27, CH $)_{3}$, $1.18(m, 2 \mathrm{H}, \mathrm{H}-21), 1.18\left(\mathrm{~s}, \mathrm{H}-29, \mathrm{CH}_{3}\right), 0.97\left(\mathrm{~s}, \mathrm{H}-25, \mathrm{CH}_{3}\right), 0.96\left(\mathrm{~s}, \mathrm{H}-23, \mathrm{CH}_{3}\right), 0.92\left(d, \mathrm{H}-30, \mathrm{CH}_{3}, \mathrm{~J}=6.6\right), 1.26$ $(m, 1 \mathrm{H}, \mathrm{H}-20), 1.22(m, 1 \mathrm{H}, \mathrm{H}-5), 0.84\left(\mathrm{~s}, \mathrm{H}-24, \mathrm{CH}_{3}\right), 0.74\left(s, \mathrm{H}-26, \mathrm{CH}_{3}\right) .{ }^{13} \mathrm{C}-\mathrm{NMR}\left(100 \mathrm{MHz}, \mathrm{CD}_{3} \mathrm{OD}\right) \delta 177.4$ (C-28), 138.2 (C-13), 128.2 (C-12), 94.5 (C-1'), 78.8 (C-3), 77.2 (C-3'), 76.9 (C-5'), 72.5 (C-2'), 72.3 (C-19), 69.8 (C$\left.4^{\prime}\right), 65.8$ (C-2), 61.1 (C-6'), 53.6 (C-18), 47.9 (C-5), 47.0 (C-9), 46.8 (C-17), 41.4 (C-1), 41.4 (C-20), 41.2 (C-14), 40.1 (C-8), 38.1 (C-10), 36.9 (C-22), 38 (C-4), 32.7 (C-7), 28.3 (C-15), 27.9 (C-23), 25.8 (C-21), 25.7 (C-29), 25.1 (C-16), 23.4 (C-11), 23.4 (C-27), 21.1 (C-24), 17.9 (C-6), 16.4 (C-26), 15.7 (C-25), 15.2 (C-30). ${ }^{1} \mathrm{H}$ NMR and ${ }^{13} \mathrm{C}$ NMR data were in agreement with data given in the literature for Kaji-ichigoside $\mathrm{F}_{1}$ [46] (Figure S5-S13).

\subsubsection{Compound 4 (2a, 3 $\beta, 19 a$ trihydroxyurs-12-en-28-O- $\beta$-D-glucopyranoside)}

${ }^{1} \mathrm{H}$ NMR $\left(400 \mathrm{MHz}, \mathrm{CD}_{3} \mathrm{OD}\right) \delta 5.30$ ( $\left.d, 1 \mathrm{H}, \mathrm{H}-1^{\prime}, J=8.1\right), 5.2$ (brs, 1H, H-12), 3.55 (m, 1H, H-2), 2.83 (d, $1 \mathrm{H}, \mathrm{H}-3, \mathrm{~J}=9.7), 3.70,3.61\left(m, 2 \mathrm{H}, \mathrm{H}-6^{\prime}\right), 3.35-3.2(m, 1 \mathrm{H}$, sugar protons, H-2', H-3', H-4' , H-5' $), 2.5(m, 2 \mathrm{H}, \mathrm{H}-$ 16), 2.43 (s, 1H, H-18), 1.9 (m, 2H, H-11), 1.89 (m, 1H, H-9), 1.81 (s, 2H, H-15), 1.72, 1.55 ( $m, 2 \mathrm{H}, \mathrm{H}-22), 1.48$ (m, 2H, H-7), 1.7 (m, 2H, H-21), 1.45 (d, 2H, H-6, J = 10.2), 1.25 (s, H-27, $\left.\mathrm{CH}_{3}\right), 1.25$ (m, 1H, H-20), 1.1 (s, H-29, CH $)_{3}$, 0.90 (s, H-25, $\left.\mathrm{CH}_{3}\right), 0.90$ (s, H-23, $\left.\mathrm{CH}_{3}\right), 0.86\left(d, \mathrm{H}-30, \mathrm{CH}_{3}, J=6.5\right), 0.8(m, 2 \mathrm{H}, \mathrm{H}-1), 0.78(m, 1 \mathrm{H}, \mathrm{H}-5), 0.73(s$, $\left.\mathrm{H}-24, \mathrm{CH}_{3}\right), 0.69$ (s, H-26, $\left.\mathrm{CH}_{3}\right) .{ }^{13} \mathrm{C}-\mathrm{NMR}\left(100 \mathrm{MHz}, \mathrm{CD}_{3} \mathrm{OD}\right) \delta 177.1(\mathrm{C}-28), 138.3(\mathrm{C}-13), 128.1(\mathrm{C}-12), 94.4(\mathrm{C}-$ $\left.1^{\prime}\right), 83.1$ (C-3), 77.2 (C-3'), 76.9 (C-5'), 72.4 (C-2'), 72.2 (C-19), 69.7 (C-4'), 68.1 (C-2), 61 (C-6'), 53.5 (C-18), 55 (C5), 47.2 (C-9), 47.8 (C-17), 46.9 (C-1), 41.5 (C-20), 41.3 (C-14), 39.9 (C-8), 37.8 (C-10), 36.9 (C-22), 39.1 (C-4), 32.7 (C-7), 28.2 (C-15), 27.9 (C-23), 25.8 (C-21), 25.8 (C-29), 25.1 (C-16), 23.4 (C-11), 23.3 (C-27), 16.2 (C-24), 18.3 (C6), 16.0 (C-26), 15.7 (C-25), 15.2 (C-30). ${ }^{1} \mathrm{H}$ NMR and ${ }^{13} \mathrm{C}$ NMR data were in agreement with data given in the literature for $2 a, 3 \beta, 19 a$ trihydroxyurs-12-en-28-O- $\beta$-D-glucopyranoside [47-49] (Figure S14-S24).

\subsubsection{Compound 5 (2a,3 $3,19 a, 23 \beta$-tetrahydroxyurs-12-en-28-O- $\beta$-D-glucopyranoside)}

${ }^{1} \mathrm{H}$ NMR (400 MHz, CD $\left.3 \mathrm{OD}\right) \delta 5.23\left(d, 1 \mathrm{H}, \mathrm{H}-1^{\prime}, J=8.1\right), 5.23(s, 1 \mathrm{H}, \mathrm{H}-12), 3.75,3.62\left(m, 2 \mathrm{H}, \mathrm{H}-6^{\prime}\right), 3.62$ $(d m, 1 \mathrm{H}, \mathrm{H}-2 \mathrm{~J}=8.5), 3.2,3.42(d, 2 \mathrm{H}, \mathrm{H}-23, \mathrm{~J}=11.1), 3.3-3.25(m, 1 \mathrm{H}$, sugar protons, H-2' , H-3', H-4', H-5' $), 3.28$ (over loaded sugar protons 1H, H-3), 2.5 (ddd, 2H, H-16, J = 4.24, 13.2), 2.43 (s, 1H, H-18), 1.94 (m, 2H, H-11), 1.76, 1.55 ( $m, 2 \mathrm{H}, \mathrm{H}-22), 1.75$ ( $m, 2 \mathrm{H}, \mathrm{H}-15), 1.7$ ( $m, 1 \mathrm{H}, \mathrm{H}-9), 1.7$ ( $m, 1 \mathrm{H}, \mathrm{H}-5), 1.7$ ( $m, 2 \mathrm{H}, \mathrm{H}-21), 1.59$ ( $m, 2 \mathrm{H}, \mathrm{H}-$ 7), 1.35 (m, 2H, H-6), 1.29 (m, 1H, H-20), $1.26\left(\mathrm{~s}, \mathrm{H}-27, \mathrm{CH}_{3}\right), 1.21,0.81(m, 2 \mathrm{H}, \mathrm{H}-1), 1.12\left(s, \mathrm{H}-29, \mathrm{CH}_{3}\right), 0.95(\mathrm{~s}$, $\left.\mathrm{H}-25, \mathrm{CH}_{3}\right), 0.86\left(d, \mathrm{H}-30, \mathrm{CH}_{3}, J=4.4\right), 0.69\left(\mathrm{~s}, \mathrm{H}-26, \mathrm{CH}_{3}\right), 0.61\left(\mathrm{~s}, \mathrm{H}-24, \mathrm{CH}_{3}\right) .{ }^{13} \mathrm{C}-\mathrm{NMR}(100 \mathrm{MHz}, \mathrm{CD} 3 \mathrm{OD}) \delta$ 177.1 (C-28), 138.3 (C-13), 128.1 (C-12), 94.4 (C-1'), 77.3 (C-3'), 77.3 (C-5'), 76.9 (C-3), 72.4 (C-2'), 72.2 (C-19), 69.7 (C-4'), 68.3 (C-2), 65 (C-23), 61 (C-6'), 53.6 (C-18), 46.8 (C-5), 47.8 (C-17), 47.1 (C-9), 46.5 (C-1), 42.7 (C-4), 41.5 (C-20), 41.4 (C-14), 39.9 (C-8), 37.6 (C-10), 36.9 (C-22), 32.1 (C-7), 28.2 (C-15), 25.8 (C-21), 25.7 (C-29), 25.1 (C16), 23.4 (C-11), 23.3 (C-27), 17.8 (C-6), 16.3 (C-26), 16.2 (C-25), 15.2 (C-30), 12.5 (C-24). ${ }^{1} \mathrm{H}$ NMR and ${ }^{13} \mathrm{C}$ NMR data were in agreement with data given in the literature for $2 a, 3 \beta, 19 a, 23 \beta$-tetrahydroxyurs-12-en-28-O- $\beta$-Dglucopyranoside [50, 51] (Figure S25-S40).

\subsection{HPLC analysis in the pseudofruits and roots of $R$. pimpinellifolia}

\subsubsection{Fingerprint analysis}

In this study, fingerprint analysis of the root extracts of $R$. pimpinellifolia has been carried out for the first time via a method that is described in the literature [52]. The correlation coefficient, regression equation, LOD, and LOQ were determined as shown in Table 1. (The amount of the phenolic content of the plant was expressed as $\mathrm{mg} / \mathrm{g}$.)

The first three major compounds in the pseudofruit were found to be benzoic acid (21.9115 mg/g dry extract ), caffeic acid (12.5583 mg/g dry extract), chlorogenic acid (4.8085 mg/g dry extract) respectively. The amount of total phenolic compounds determined in the dry extract of the pseudofruit was $31.1937 \mathrm{mg} / \mathrm{g}$ (Table 2, Figure 2).

The first three major compounds in the root extract were found to be benzoic acid (11.3593 mg/g dry extract), protocatechuic aldehyde $(4.1719 \mathrm{mg} / \mathrm{g}$ dry extract), and vanillic acid (1.5754 mg/g dry extract) respectively. The amount of total phenolic compounds determined in the dry extract of the pseudofruit was $9.8909 \mathrm{mg} / \mathrm{g}$ (Table 3; Figure 3). 


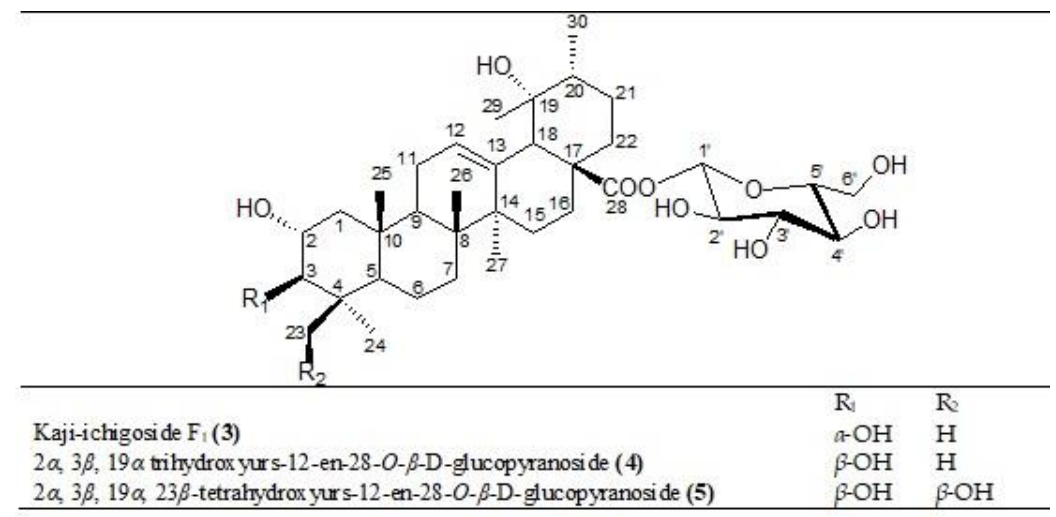

Figure 1. Isolated triterpene compounds from the roots of Rosa pimpinellifolia.

Table 1. Method validation data for thirteen compounds determined via HPLC.

\begin{tabular}{lcccc}
\hline Compounds & $\begin{array}{c}\text { LOD } \\
(\boldsymbol{\mu g} / \mathbf{m L})\end{array}$ & $\begin{array}{c}\text { LOQ } \\
(\boldsymbol{\mu g} / \mathbf{m L})\end{array}$ & $\begin{array}{c}\text { Correlation } \\
\text { coefficient }(\mathbf{r})\end{array}$ & $\begin{array}{c}\text { Regression } \\
\text { equation }\end{array}$ \\
\hline 1- Gallic acid & 0.03 & 0.12 & 0.9935 & $\mathrm{Y}=46685 \mathrm{X}-33209$ \\
2- Protocatechuic acid & 0.04 & 0.11 & 0.9984 & $\mathrm{Y}=39214 \mathrm{X}-27944$ \\
3- Protocatechuic aldehyde & 0.03 & 0.09 & 0.9968 & $\mathrm{Y}=46438 \mathrm{X}+6147.1$ \\
4- -Hydroxybenzoic acid & 0.02 & 0.07 & 0.9974 & $\mathrm{Y}=39080 \mathrm{X}-10794$ \\
5- Chlorogenic acid & 0.12 & 0.35 & 0.9930 & $\mathrm{Y}=9208.8 X-399.4$ \\
6- Vanillic acid & 0.02 & 0.08 & 0.9980 & $\mathrm{Y}=49369 X-63110$ \\
7- Caffeic acid & 0.15 & 0.15 & 0.9973 & $\mathrm{Y}=27764 X-9126.7$ \\
8- Vanillin & 0.02 & 0.07 & 0.9976 & $\mathrm{Y}=38753 X-1671.6$ \\
9- Syringaldehyde & 0.11 & 0.34 & 0.9982 & $\mathrm{Y}=13655 \mathrm{X}-2503.5$ \\
10- -Coumaric acid & 0.03 & 0.11 & 0.9955 & $\mathrm{Y}=53747 \mathrm{X}-39534$ \\
11- Ferulic acid & 0.06 & 0.19 & 0.9975 & $\mathrm{Y}=81674 X-55584$ \\
12- Sinapic acid & 0.12 & 0.38 & 0.9997 & $\mathrm{Y}=63367 \mathrm{X}-44638$ \\
13- Benzoic acid & 0.28 & 0.86 & 0.9967 & $\mathrm{Y}=6422 \mathrm{X}-11532$ \\
\hline
\end{tabular}

Table 2. The concentration of compounds in R. pimpinellifolia pseudofruit extract.

\begin{tabular}{lc}
\hline Compounds & Concentration $(\mathbf{m g} / \mathbf{g}$ dry extract) \\
1-Gallic acid & $*$ \\
2-Protocatechuic acid & 1.0800 \\
3-Protocatechuic aldehyde & 0.4937 \\
4- -Hydroxybenzoic acid & 4.8085 \\
5-Chlorogenic Acid & 0.6592 \\
6-Vanillic Acid & 12.5583 \\
7-Caffeic Acid & 0.8957 \\
8-Vanillin & 4.2989 \\
9-Syringaldehyde & 0.7297 \\
10-p-Coumaric Acid & 1.0225 \\
11-Ferulic Acid & 4.6472 \\
12-Sinapic Acid & 21.9115 \\
13-Benzoic Acid &
\end{tabular}

\subsection{Determination of free fatty acids}

As a result of Soxhlet extraction, we determined that $4.74 \%$ of seeds of R. pimpinellifolia is fixed oil. After hydrolysis of the oil and esterification of the fatty acids with $\mathrm{MeOH}$, we detected fatty acid composition by using GC and GC-MS. Thus, the composition of R. pimpinellifolia seed oil contains mainly fatty acids (98.5\%) in which unsaturated fatty acids are found as $93.40 \%$. The major unsaturated fatty acids were linoleic acid $\left(\mathrm{C}_{18: 2}\right)(51.4 \%)$ and homo- $\gamma$-linolenic acid $\left(\mathrm{C}_{20: 3}\right)(41.2 \%)$ (Table 4$)$. 


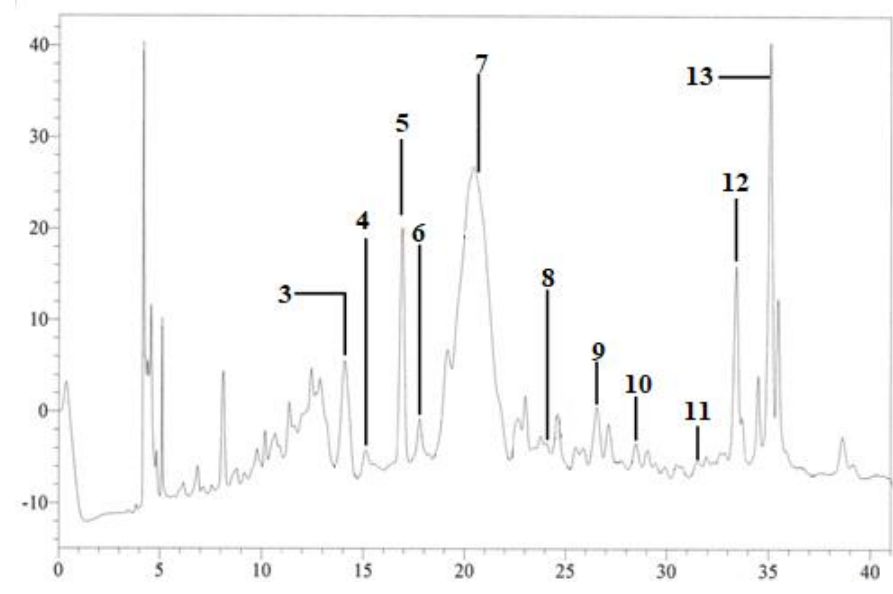

Figure 2. Compounds in R. pimpinellifolia pseudofruit extract.

Table 3. The concentration of compounds in the root extract of $R$. Pimpinellifolia

\begin{tabular}{lc}
\hline Compounds & Concentration $(\mathbf{m g} / \mathbf{g}$ dry extract) \\
\hline 1-Gallic acid & 0.1114 \\
2-Protocatechuic acid & 0.1060 \\
3-Protocatechuic aldehyde & 4.1719 \\
4- -Hydroxybenzoic acid & 0.0953 \\
5-Chlorogenic Acid & 0.2590 \\
6-Vanillic Acid & 1.5754 \\
7-Caffeic Acid & 0.5791 \\
8-Vanillin & 0.1199 \\
9-Syringaldehyde & 0.6990 \\
10-p-Coumaric Acid & 0.4658 \\
11-Ferulic Acid & 0.1880 \\
12-Sinapic Acid & 1.5201 \\
13-Benzoic Acid & 11.3593 \\
\hline
\end{tabular}

\section{DISCUSSION}

In this study, we determined the chemical composition and the possible health-beneficial compounds of $R$. pimpinellifolia pseudofruits, seeds, and roots. We determined the fatty acids composition of $R$. pimpinellifolia's seed oil and 11 compounds from pseudofruits. Additionally, We determined 13 compounds from the roots of $R$. pimpinellifolia for the first time.

In the NMR studies of compound 5, we determined $J_{2,3}=8.5 \mathrm{~Hz}$ which shows trans structure of $\mathrm{H}-2$ and $\mathrm{H}-3$ according to each other. $\mathrm{CH}_{2} \mathrm{OH}$ attached to $\mathrm{C}-4$ gave an $\mathrm{AB}$ system $\left(J_{23 a, 23 b}=11.1 \mathrm{~Hz}\right)$ at $\mathrm{d}=3.42$ and 3.18 ppm as doublets which exactly confirms attached $\mathrm{CH}_{2} \mathrm{OH}$ and $\mathrm{CH}_{3}$ to $\mathrm{C}-4$. In 1984, Seto et al. [49] reported a very similar compound to compound 5 in which all functionalities are the same but only $\mathrm{CH}_{2} \mathrm{OH}$ attached to C-4 is structured as alfa. Therefore, to elucidate the structure of $\mathrm{CH}_{2} \mathrm{OH}$ we needed further 2D NMR studies.

The intensity of the methyl signal of $\mathrm{H}_{3} \mathrm{C}(24)(0.61 \mathrm{ppm})$ increased when the signal of $\mathrm{H}-3$ (3.28 ppm) was irradiated in the NOE experiment. However, the intensity of the signal of H-2 (3.62 ppm) did not increase as expected. These show that $\mathrm{H}-3$ and $\mathrm{H}_{3} \mathrm{C}(24)$ were in the same directions and $\mathrm{H}-2$ and $\mathrm{H}-3$ were in different directions (Figure S38- S40).

Shameh et al. reported the phenolic contents of pseudofruits of 5 different Rosa species $(R$. canina, $R$. moschata, $R$. damascene, $R$. webbiana, $R$. hemisphaerica) and stated that chlorogenic acid and gallic acid were the main components [53].

In the study by Okan et al., it is reported that R. pimpinellifolia pseudofruits have a high total phenolic and flavonoid content and contain phenolic compounds such as gallic acid, protocatechuic acid, catechin, and quercetin. Besides, some enzyme inhibitory effects (acetylcholinesterase, xanthin oxidase, and urease) were examined and their potential activities were shown. In our study, gallic acid and protocatechuic acid were not detected. While caffeic acid was the major component, it was not detected in their study [54]. These distinct results obtained from the same plants can arise from various factors including location, altitude, and climate [53]. 


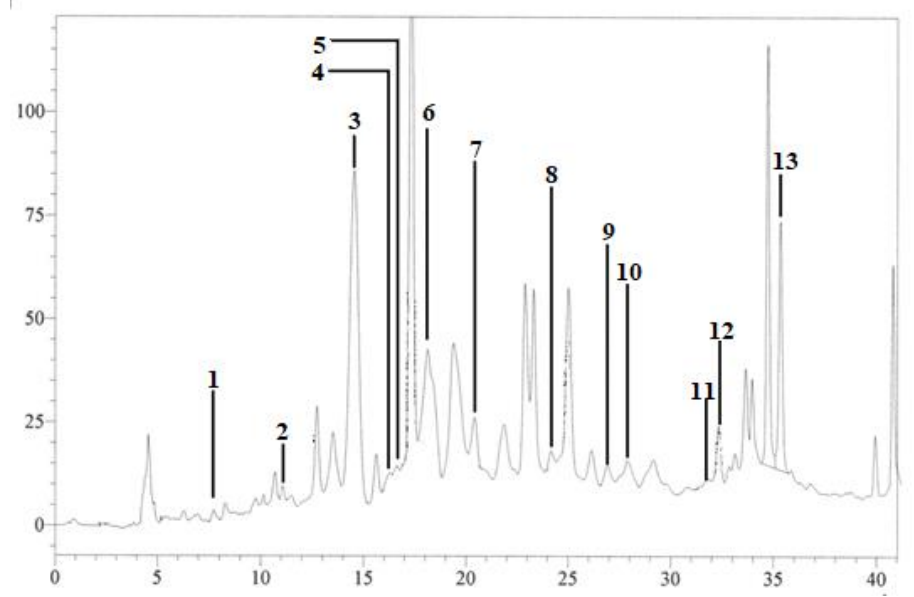

Figure 3. Compounds in R. pimpinellifolia root extract.

Table 4. The fatty acids composition of R. pimpinellifolia's seed oil (\%) a, b.

\begin{tabular}{|c|c|c|c|c|c|}
\hline Fatty acid & Symbol & Serial & $\%$ Area & $\begin{array}{l}\text { Retention } \\
\text { time }\end{array}$ & $\begin{array}{l}\text { Retention } \\
\text { indices }\end{array}$ \\
\hline Lauric acid & C 12:0 & - & 0.1 & 37.22 & 1525 \\
\hline Tetradecanoic acid & C 14:0 & - & 0.1 & 44.29 & 1725 \\
\hline Pentadecanoic acid & C 15:0 & - & 0.1 & 47.59 & 1826 \\
\hline Palmitic acid & C 16:0 & - & 0.2 & 50.14 & 1906 \\
\hline Heksadecanoic acid & C 16:0 & - & 3.0 & 50.81 & 1928 \\
\hline Heksadecadienoic acid & C 16:2 & $\omega-12$ & 0.1 & 52.89 & 1997 \\
\hline 8,11,14-Dokosatrienoic acid & C 22:3 & $\omega-8$ & 0.1 & 53.10 & 2004 \\
\hline Heptadecanoic acid & C 17:0 & - & 0.1 & 53.79 & 2027 \\
\hline Linoleic acid & C $18: 2$ & $\omega-6$ & 51.4 & 56.21 & 2111 \\
\hline Homo- $\gamma$-linolenic acid & C 20:3 & $\omega-6$ & 41.2 & 56.40 & 2118 \\
\hline Stearic acid & C 18:0 & - & 1.5 & 56.78 & 2131 \\
\hline 11,14,17-Eikozatrienoic acid & C 20:3 & $\omega-3$ & 0.1 & 57.32 & 2150 \\
\hline 11Z-Eikozenoic acid & C 20:1 & $\omega-9$ & 0.6 & 61.52 & 2304 \\
\hline$\Sigma$ & 98.50 & & & & \\
\hline$\Sigma$ saturated & 5.10 & & & & \\
\hline Sunsaturated & 93.40 & & & & \\
\hline
\end{tabular}

Phenolic contents of the root of R. pimpinellifolia were also measured for the first time in our study. The amount of phenolic substance of the roots was less than that of the pseudofruit. The total amount of phenolic acids were detected as $31.24 \mathrm{mg} / \mathrm{g}$ extract in pseudofruit and $9.795 \mathrm{mg} / \mathrm{g}$ dry extract in the root.

In our study, we detected linoleic acid, homo- $\gamma$-linolenic acid, and stearic acid content as $51.4 \%, 41.2 \%$, $1.5 \%$, respectively. Thus, for the first time, we herein report that the presence of homo- $\gamma$-linolenic acid as fatty acid in the seeds of R. pimpinellifolia has not been reported in the other Rosa species. We suppose that these differences are thought to be due to the location, climate, and stress conditions of the collected plant material. Our comment is also supported by Çakır et al 2004 who suggest that the chemical contents of the same species are changeable according to location [55]. The ratio of homo- $\gamma$-linolenic acid was found to be very high in $R$. pimpinellifolia seeds. Therefore, it may be thought that $R$. pimpinellifolia seed oil can be used in medical materials or dietary supplements. In this context, further biological and chemical studies are required.

In the study conducted by Murathan et al., the fatty acids consist of four Rosa species, one of which was R. pimpinellifolia. Researchers reported that R. pimpinellifolia had the highest amount of linoleic acid (41.21\%) and stearic acid (19.2\%) [56].

In a study investigating the oil content and fatty acid composition of different Rosa species, Ercisli et al. reported the oil content changes between $4.60-5.37 \%$ in which the ratio of unsaturated fatty acids is between 77.80-91.85\% [57]. 


\section{CONCLUSION}

From the results of the present research, it can be concluded that the traditional use of $R$. pimpinellifolia roots is due to the rich triterpenes and phenolic compounds in the plant's content. Also, the pharmacological and biological activities of seed oils, and the isolated active ingredients should be investigated.

\section{MATERIALS AND METHODS}

\subsection{General experimental procedures}

${ }^{1} \mathrm{H}$ NMR and ${ }^{13} \mathrm{C}$ NMR spectra were recorded with a Varian Mercury plus spectrometer at $400 \mathrm{MHz}$ and $100 \mathrm{MHz}$. Sephadex LH-20 (Sigma-Aldrich) and silica gel (Kieselgel 60, 0.063-0.2 mm Merck 7734 and $0.040-$ $0.063 \mathrm{~mm}$ Merck 9385 and LiChroprep RP-18, 25-40 $\mu \mathrm{m}$, Merck 9303) for column chromatography (CC); silica gel 60 F254 (Merck, 05554) for TLC were used. TLC spots were detected with a UV lamp and spraying $1 \%$ Vanillin/ $\mathrm{H}_{2} \mathrm{SO}_{4}$ and heating at $120{ }^{\circ} \mathrm{C}$ for 1-2 min. Solvents used in isolation and solvent system are ethyl acetate, formic acid, methanol, $\mathrm{H}_{2} \mathrm{SO}_{4}, \mathrm{H}_{2} \mathrm{O}, \mathrm{HCl}$, hexane, chloroform (Merck), vanillin (Fluka). HPLC analysis was practiced using a Shimadzu liquid chromatography (Shimadzu Corporation, LC 20 AT, Kyoto, Japan) and C18 column (Zorbax, $4.6 \mathrm{~mm} \times 150 \mathrm{~mm}, 5 \mu \mathrm{m}$ particle size). GC analysis was carried out using a Shimadzu 2010 Plus gas chromatography coupled to a Shimadzu QP2010 Ultra mass selective detector.

\subsection{Plant material}

R. pimpinellifolia roots were collected in Köşk village, Erzurum, Turkey (altitude 1900 m) in September 2013 and were authenticated by Prof. Dr. Ufuk Özgen. A voucher specimen (ATA 9876) has been deposited in Atatürk University Science Faculty.

\subsection{Extraction and isolation}

Schematic isolation steps were shown in Figure 4.

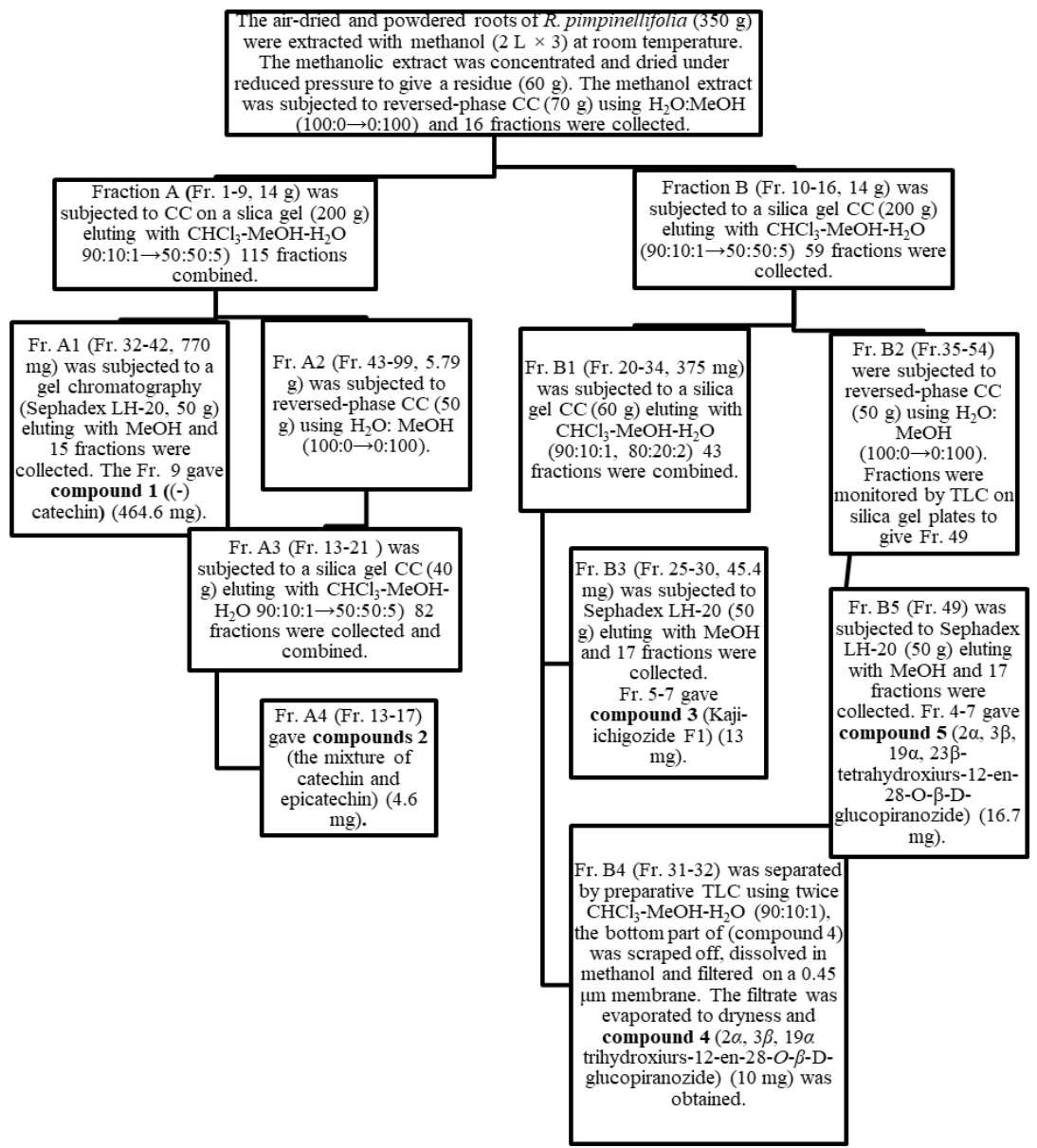

Figure 4. The purification pathway of pure compounds from the roots of R. Pimpinellifolia. 


\subsection{HPLC analysis in pseudofruits and roots of Rosa pimpinellifolia}

\subsubsection{Preparation of the extracts}

The dried and powdered roots and pseudofruits of the plant $(1 \mathrm{~g})$ were extracted with $20 \mathrm{~mL}$ methanol for $12 \mathrm{~h}$ at $25{ }^{\circ} \mathrm{C}$ in the mechanical stirrer. The solvent was removed under vacuum. The dried methanol extracts were dissolved in HPLC grade methanol $(10 \mathrm{mg} / \mathrm{mL})$ and filtered through $0.45 \mu \mathrm{m}$ membranes.

\subsubsection{Fingerprint analysis}

The modified method was run for 41 minutes to determine compounds. For gradient elution, the mobile phase consists of $0.5 \%(\mathrm{v} / \mathrm{v})$ acetic acid in HPLC-grade water/acetonitrile (50:50) (Solvent A) and 2\% (v/v adjust to $\mathrm{pH} 2.85$ ) acetic acid in HPLC-grade water (Solvent B) as mobile phase. The flow rate was $1.2 \mathrm{~mL} / \mathrm{min}$. The injection volume was $20 \mu \mathrm{L}$ for this method. The method was studied with a diode array detector at 270 and $340 \mathrm{~nm}$ at $25^{\circ} \mathrm{C}$ [52].

\subsection{Determination of free fatty acids}

\subsubsection{Oil extraction}

The dried and powdered seeds of R. pimpinellifolia $(50 \mathrm{~g})$ were extracted with diethyl ether in a Soxhlet apparatus for 2 hours at $75{ }^{\circ} \mathrm{C}$. Then, the solvent was evaporated under reduced pressure to obtain a crude fixed oil (yields:2.37 $\mathrm{g}, 4.74 \%$ )

\subsubsection{Gas chromatography-mass spectrometry (GC-MS) analysis}

Fatty Acid Methyl Esters (FAMEs) in $1 \mu \mathrm{L}$ HPLC grade hexane were injected and analyzed by GC-MS under the following conditions. GC-MS analyses were made as described previously [58]. The GC-MS conditions are set out in the following (Table 5).

Table 5. The GC-MS conditions.

\begin{tabular}{ll}
\hline \multirow{2}{*}{ Column temperature } & $\begin{array}{l}: \text { The initial temperature was } 60^{\circ} \mathrm{C} \text { for } 2 \text { min, which } \\
\text { was increased to } 240{ }^{\circ} \mathrm{C} \text { at } 3{ }^{\circ} \mathrm{C} / \mathrm{min} \text {, the final } \\
\text { temperature of } 250^{\circ} \mathrm{C} \text { was held for } 4 \mathrm{~min}\end{array}$ \\
\hline Injector temperature & $: 250^{\circ} \mathrm{C}$ \\
Detector temperature & $: 240^{\circ} \mathrm{C}$ \\
Carrier gas & $:$ Helium $(99.999 \%)$ \\
Flow rate & $: 1 \mathrm{~mL} / \mathrm{min}$ \\
Injection volume & $: 1 \mu \mathrm{L}$ \\
Split ratio & $: 1 / 20$ \\
Analyse time & $: 60 \mathrm{~min}$ \\
MS scanning range $(\mathbf{m} / \mathbf{z})$ & $:(40-450 \mathrm{~m} / \mathrm{z})$ \\
Electron impaction ionization & $: 70 \mathrm{eV}$ \\
\hline
\end{tabular}

The Wiley and Nist libraries were used to identify the peaks in GC-MS chromatograms obtained from the analyzes. Relative percentages of peaks of fatty acids were calculated using Agilent Software. All samples were injected 2 times and the results expressed as the average of the values obtained after 2 injections.

\subsubsection{Identification of constituents}

Constituents of the FAMEs were identified by comparing their indices that were determined by the Kovats method using FAMEs $\left(\mathrm{C}_{4}-\mathrm{C}_{24}\right)$ as standards. Mass spectra of FAMEs were determined with FFNSC1.2, W9N11 mass spectral libraries, and with published data [56-60] (Figure S41).

\subsubsection{Esterification of the fixed oil}

The obtained lipid samples were warmed with $2 \mathrm{~N} \mathrm{KOH}$ in $\mathrm{MeOH}$ at $80{ }^{\circ} \mathrm{C}$ for 2 hours. The solution was cooled. Then $2 \mathrm{~N} \mathrm{HCl}$ was added to neutralize the mixture. A neutralized mixture was extracted with $n$ hexane. The part of $\mathrm{n}$-hexane was separated and mixed with $5 \mathrm{~mL}$ water to wash, dried with anhydrous $\mathrm{Na}_{2} \mathrm{SO}_{4}$, and filtered. $2 \mathrm{~mL}$ methanol was added to the $40 \mathrm{mg}$ sample to dissolved in a test tube and the solutions were cooled in an ice bath; then $\mathrm{BBr}_{3}$ was added, dropwise. The test tube was waited in a boiling water bath at $100{ }^{\circ} \mathrm{C}$ for 6 hours and cooled. Then $3 \mathrm{~mL}$ water was added and extracted with $2 \mathrm{~mL} n$-hexane 
two times. $4 \mathrm{~mL}, 2 \% \mathrm{KHCO}_{3}$ was added to the hexane layers, dried over anhydrous $\mathrm{Na}_{2} \mathrm{SO}_{4}$, and filtered. The organic solvent was evaporated to yield FAMEs. Fatty acid methyl esters were obtained from the lipid sample as described in the literature with minor modifications [60].

Acknowledgements: The authors thank Prof. Dr. Özlem Barış, Dr. Tevfik Darıyemez, and Ataturk University Methodology Support Office for editing and proofreading.

Author contributions: Concept - L.G., U.Ö., H.S.; Design - L.G., U.Ö., H.S.; Supervision -U.Ö., H.S. N.Y.; Resources L.G., U.Ö., H.S.; Materials - L.G., U.Ö., H.S., N.Y.; Data Collection and/or Processing - L.G., S. Ö. Ş., M.B.; Analysis and/or Interpretation - L.G., U.Ö., S.Ö.Ş., M.B., G.Ç.; Literature Search - L.G., U.Ö., H.S.; Writing - L.G., HS.; Critical Reviews - L.G., U.Ö., H.S., S.Ö.Ş., M.B., G.Ç., N.Y.

Conflict of interest statement: The authors declared no conflict of interest.

\section{Appendix A. Supplementary Material}

Supplementary material related to this article can be accessed at https://dx.doi.org/10.29228/jrp.6 .

\section{REFERENCES}

[1] Davis PH. Nilsson Ö. Rosa L. In Flora of Turkey and the East Aegean Islands vol 4. Edinburgh University Press, UK, 1972, pp 106-128.

[2] Baytop T, Türkiye'de Bitkiler ile Tedavi. Istanbul Üniversitesi, Istanbul, Türkiye 1999.

[3] Özgen U, Kaya Y, Houghton P. Folk medicines in the villages of Ilıca District (Erzurum, Turkey). Turk J Biol. 2012; 36(1): 93-106. [CrossRef]

[4] Tetik F, Civelek S, Cakilcioglu U. Traditional uses of some medicinal plants in Malatya (Turkey). J Ethnopharmacol. 2013; 146 (1): 331-346. [CrossRef]

[5] Gürhan G, Ezer N. Halk arasında hemoroit tedavisinde kullanılan bitkiler-I. Hacettepe Univ Eczacı Fak Derg. 2004; 24 (1): 37-55.

[6] Altundag E, Ozturk M. Ethnomedicinal studies on the plant resources of East Anatolia, Turkey. Procedia Soc Behav Sci. 2011; 19: 756-777. [CrossRef]

[7] Coşkun M, Kurucu S, Kartal M. HPLC analysis of ascorbic acid in the fruits of some Turkish Rosa species. Sci Pharm. 1997; 65: 169-174.

[8] Vertuani S, Bosco E, Testoni M, Ascanelli S, Azzena G, Manfredini S. Antioxidant herbal supplements for hemorrhoids. Developing a new formula. Nutrafoods. 2004; 3: 19-26.

[9] Ullah M, Khan H, Zubair H, Shamim U, Hadi S. The antioxidant ascorbic acid mobilizes nuclear copper leading to a prooxidant breakage of cellular DNA: implications for chemotherapeutic action against cancer. Cancer Chemother Pharmacol. 2011; 67 (1): 103-110. [CrossRef]

[10] Roman I, Stanila A, Stanila S. Bioactive compounds and antioxidant activity of Rosa canina L. biotypes from spontaneous flora of Transylvania. Chem Cent J. 2013; 7(1): 73. [CrossRef]

[11] Shin I-C, Jeong K-J, Shim T-H, Oh H-S, Park S-K, Cheung E-H, Kim S-N, Kim G-G, Choi D-S, Kwon Y-S. Catechin content and antioxidative effect from Rosa davurica Pall. Korean J Physiol Pharmacol. 2002; 33 (3): 177-181.

[12] Ahmad N, Anwar F. Rose hip (Rosa canina L.) oils. In: Essential oils in food preservation, flavor and safety. Elsevier. 2016; 667-675.

[13] Bruneton J. Pharmacognosy, phytochemistry, medicinal plants. vol Ed. 2. Technique et Documentation Lavoisier, Paris 1993.

[14] Cunnane S, Anderson M. Pure linoleate deficiency in the rat: influence on growth, accumulation of $n-6$ polyunsaturates, and [1-14C] linoleate oxidation. J Lipid Res. 1997; 38 (4): 805-812.

[15] Schmitz G, Ecker J. The opposing effects of n- 3 and n- 6 fatty acids. Prog Lipid Res. 2008; 47 (2): 147-155. [CrossRef]

[16] Horrobin D. Nutritional and medical importance of gamma-linolenic acid. Prog Lipid Res. 1992; 31 (2): $163-194$. [CrossRef]

[17] Feller SE, Gawrisch K. Properties of docosahexaenoic-acid-containing lipids and their influence on the function of rhodopsin. Curr Opin Struct Biol. 2005; 15 (4): 416-422. [CrossRef] 
[18] Kumar N, Bhandari P, Singh B, Gupta AP, Kaul VK. Reversed phase-HPLC for rapid determination of polyphenols in flowers of Rosa species. J Sep Sci. 2008; 31 (2): 262-267. [CrossRef]

[19] Mikanagi Y, Yokoi M, Ueda Y, Saito N. Flower flavonol and anthocyanin distribution in subgenus Rosa. Biochem Syst Ecol. 1995; 23 (2): 183-200. [CrossRef]

[20] Gao X, Yang L, Shu L, Shen Y, Zhang Y, Hu Q. Aurone constituents from the flowers of Rosa rugosa and their biological activities. Heterocycles. 2012; 85 (8): 1925-1931. [CrossRef]

[21] Çoruh N, Özdoğan N. Identification and quantification of phenolic components of Rosa heckeliana Tratt roots. J Liq Chromatogr Relat. 2015; 38 (5): 569-578. [CrossRef]

[22] Gao XM, Shu LD, Yang LY, Shen YQ, Zhang YJ, Hu QF. Phenylethanoids from the flowers of Rosa rugosa and their biological activities. Bull Korean Chem Soc. 2013; 34 (1): 246-248. [CrossRef]

[23] Liu D, Zhu S, Ma R, Zhang J, Li H, Chen H. Triterpenoids from the roots of Rose odorata var. gigantean. Chin J Nat Med. 2010; 8 (1): 12-15. [CrossRef]

[24] Stoyanova-Ivanova B, Iochkova I, Mladenova K, Daskalov R. Content and composition of neutral components in wax from Rosa canina flowers. Dokl Bolg Akad Nauk. 1979; 32 (11): 1503-1506.

[25] Hashidoko Y. The phytochemistry of Rosa rugosa. Phytochemistry. 1996; 43 (3): 535-549. [CrossRef]

[26] Novruzov EN. Pigments of species in the genus Rosa and their chemotaxonomic value. Acta Horticulturae 690. (Proceedings of the 1st International Rose Hip Conference, 2004). 2005; 225-230.

[27] Ghazghazi H, Miguel MG, Hasnaoui B, Sebei H, Ksontini M, Figueiredo AC, Pedro LG, Barroso JG. Phenols, essential oils and carotenoids of Rosa canina from Tunisia and their antioxidant activities. Afr J Biotechnol. 2010; 9 (18): 27092716.

[28] Al-Rehaily AJ, Al-Howiriny TA, Bizzo HR Essential oil of Rosa abyssinica R. Br. from Saudi Arabia. J Essent Oil Res. 2003; 15 (5): 344-345. [CrossRef]

[29] Yoshida T, Jin Z, Okuda T. Tannins of rosaceous medicinal plants. Part 10. Hydrolyzable tannin oligomers from Rosa davurica. Phytochemistry. 1991; 30(8): 2747-2752. [CrossRef]

[30] Park JC, Hwang YH, Choi DR, Jung DY, Park JG, Hur JM, Kim SJ, Kim SN, Kim MS. A triterpenoid glucoside and phenolic compounds from Rosa davurica. Nat Prod Sci. 2003; 9(1): 31-33.

[31] Yang SC, Fang JM, Cheng YS. Chemical constituents from the root and aerial parts of Rosa taiwanensis. J Chın Chem Soc. 1995; 42(3): 573-577. [CrossRef]

[32] Li Y, Hu L, Lou F. Studies on the constituents of Rosa multiflora Thunb. Zhongguo Yaoke Daxue Xuebao. 2002; 33(3): 184-187.

[33] Park KH, Kim SK, Choi SE, Kwon JH, Oh MH, Lee MW. Three new stereoisomers of condensed tannins from the roots of Rosa multiflora. Chem Pharm Bull. 2010; 58(9): 1227-1231. [CrossRef]

[34] Yeo H, Chin YW, Park SY, Kim J. Lignans of Rosa multiflora roots. Arch Pharm Res. 2004; 27(3): 287-290. [CrossRef]

[35] Li S, Zhai X, Wang T, Ma W, Hu J, Wang S, Li N, Wang K. Flavonoids and triterpenoids from the roots of Rosa laevigata. J Mex Chem Soc. 2014; 58(4): 374-377.

[36] He RR, Yao XS, Yao N, Wang M, Dai Y, Gao H, Yu Y, Kurihara H. Protective effects of radix Rosa laevigata against Propionibacterium acnes and lipopolysaccharide-induced liver injury. Biosci Biotechnol Biochem. 2009; 73(5): 11291136. [CrossRef]

[37] Liu DL, Zhu S, Ma R, Zhang JZ, Li HY, Chen H. Triterpenoids from the roots of Rose odorata var. gigantean. Chin J Nat Med. 2010; 8(1): 12-15. [CrossRef]

[38] An HJ, Kim IT, Park HJ, Kim HM, Choi JH, Lee KT. Tormentic acid, a triterpenoid saponin, isolated from Rosa rugosa, inhibited LPS-induced iNOS, COX-2, and TNF- $\alpha$ expression through inactivation of the nuclear factor-kb pathway in RAW 264.7 macrophages. Int. Immunopharmacol. 2011;11(4): 504-510. [CrossRef]

[39] Coruh N, Ozdogan N. Wild-growing Rosa heckeliana Tratt.: phenolic constituents with cytotoxic and antioxidative properties. Turk J Biol. 2017; 41: 195-212. [CrossRef]

[40] Park KH, Jeong MS, Park KJ, Choi YW, Seo SJ, Lee MW. Topical application of Rosa multiflora root extract improves atopic dermatitis-like skin lesions induced by mite antigen in NC/Nga mice. Biol Pharm Bull. 2014; 37(1): 178-183. [CrossRef] 
[41] Kim IT, Ryu S, Shin JS, Choi JH, Park HJ, Lee KT. Euscaphic acid isolated from roots of Rosa rugosa inhibits LPSinduced inflammatory responses via TLR4-mediated NF-кB inactivation in RAW 264.7 macrophages. J Cell Biochem. 2012; 113(6): 1936-1946. [CrossRef]

[42] Porter EA., Van den Bos AA, Kite GC, Veitch NC, Simmonds MS. Flavonol glycosides acylated with 3-hydroxy-3methylglutaric acid as systematic characters in Rosa. Phytochemistry. 2012; 81: 90-96. [CrossRef]

[43] Mavi A, Terzi Z, Özgen U, Yildirim A, Coşkun M. Antioxidant properties of some medicinal plants: Prangos ferulacea (Apiaceae), Sedum sempervivoides (Crassulaceae), Malva neglecta (Malvaceae), Cruciata taurica (Rubiaceae), Rosa pimpinellifolia (Rosaceae), Galium verum subsp. verum (Rubiaceae), Urtica dioica (Urticaceae). Biol Pharm Bull. 2004; 27(5): 702-705. [CrossRef]

[44] Seto R, Nakamura H, Nanjo F, Hara Y. Preparation of epimers of tea catechins by heat treatment. Biosci Biotechnol Biochem. 1997; 61 (9): 1434-1439. [CrossRef]

[45] Davis AL, Cai Y, Davies AP, Lewis J. 1H and 13C NMR assignments of some green tea polyphenols. Magn Reson Chem. 1996; 34 (11): 887-890. [CrossRef]

[46] Guang-yi L. The isolation and structure of-kaji-ichigoside f1 and rosamultin. Acta Bot Sin. 1988; 4: 409-413.

[47] Wang Q, Ju P, Wang Y-F, Luo S-D. Triterpenoids from Saurauia napaulensis (Saurauiaceae). Acta Bot Yunnan. 2008; 30 (1): $121-124$.

[48] Liu DL, Zhu S, Ma R, Zhang JZ, Li HY, Chen H. Triterpenoids from the roots of Rose odorata var. gigantean. Chin J Nat Med. 2010; 8 (1): 12-15. [CrossRef]

[49] Seto T, Tanaka T, Tanaka O, Naruhashi N. $\beta$-Glucosyl esters of 19a-hydroxyursolic acid derivatives in leaves of Rubus species. Phytochemistry. 1984; 23 (12): 2829-2834. [CrossRef]

[50] De Leo M, De Tommasi N, Sanogo R, D’Angelo V, Germanò MP, Bisignano G, Braca A. Triterpenoid saponins from Pteleopsis suberosa stem bark. Phytochemistry. 2006. 67(24): p. 2623-2629. [CrossRef]

[51] Ponou BK, Teponno RB, Ricciutelli M, Quassinti L, Bramucci M, Lupidi G, Barboni L, Tapondjou LA. Dimeric antioxidant and cytotoxic triterpenoid saponins from Terminalia ivorensis A. Chev. Phytochemistry. 2010. 71(17-18): p. 2108-2115. [CrossRef]

[52] Aliyazicioglu R, Demir S, Badem M, Sener SO, Korkmaz N, Demi EA, Ozgen U, Karaoglu SA, Aliyazicioglu Y. Antioxidant, Antigenotoxic, Antimicrobial Activities and Phytochemical Analysis of Dianthus carmelitarum. Rec Nat Prod. 2017; 11 (3).

[53] Shameh S, Alirezalu A, Hosseini B, Maleki R. Fruits phytochemical composition and color parameters of twenty-one accessions of five Rosa species grown in North West Iran. J Sci Food Agric. 2019; 99(13): 5740-5751. [CrossRef]

[54] Okan O, Serencam H, Baltas N, Can Z. Some edible forest fruits their in vitro antioxidant activities, phenolic compounds and some enzyme inhibition effects. Fresenius Environ. Bull. 2019; 28: 6090-6098.

[55] Cakir A. Essential oil and fatty acid composition of the fruits of Hippophae rhamnoides L. (Sea Buckthorn) and Myrtus communis L. from Turkey. Biochem Syst Ecol. 2004; 32 (9): 809-816. [CrossRef]

[56] Murathan ZT, Zarifikhosroshahi M, Kafkas NE. Determination of fatty acids and volatile compounds in fruits of rosehip (Rosa L.) species by HS-SPME/GC-MS and Im-SPME/GC-MS techniques. Turk J Agric For. 2016; 40 (2): 269 279. [CrossRef]

[57] Ercisli S, Orhan E, Esitken A. Fatty acid composition of Rosa species seeds in Turkey. Chem Nat Compd. 2007; 43 (5): 605-606.

[58] Renda G, Celik G, Korkmaz B, Karaoglu SA, Yayli N Antimicrobial Activity and Analyses of Six Geranium L. Species with Headspace SPME and Hydrodistillation. J Essent Oil Bear Pl. 2016; 19 (8): 2003-2016. [CrossRef]

[59] Adams RP. Identification of volatile oil components by gas chromatography/mass spectroscopy. Allured Publishing Corporation, Carol Stream, IL, USA 2004.

[60] Yaylı N, Tosun G, Yayh B, Gündoğan Z, Coşkunçelebi K, Karaoğlu Ş. Altitude Variation in the Composition of Essential Oils, Fatty Acid Methyl Esters, and Antimicrobial Activities of Two Subspecies of Primula vulgaris Grown in Turkey. Nat Prod Commun. 2016; 11 (10): 1505-1510.

This is an open access article which is publicly available on our journal's website under Institutional Repository at http://dspace.marmara.edu.tr. 